\title{
The Influence of Media Exposure, Managerial Ownership, and the Indonesia Sustainability Reporting Award on Corporate Social Responsibility (CSR) Disclosure
}

\author{
Rifa Alfariz ${ }^{1^{*}}$,Harjanti Widiastuti ${ }^{1}$ \\ ${ }^{1}$ Universitas Muhammadiyah Yogyakarta, Indonesia \\ *Corresponding author.Email: widiascahyo@gmail.com
}

\begin{abstract}
This paper aimed to study whether media exposure, classified as positive media exposure and negative media exposure, managerial ownership, and the Indonesia Sustainability Reporting Award influenced the disclosure of Corporate Social Responsibility (CSR). This study's subjects were companies listed on the Indonesian Stock Exchange that published sustainability reports. The study involved 23 samples of companies observed for over two years (2017-2018), so we had 46 samples in total; these samples were chosen through purposive sampling. This study employed multiple regression analyses to examine the influence of those variables on CSR disclosure. Based on the analysis results, positive media exposure and ISR Award positively influenced CSR disclosure. In contrast, managerial ownership and negative media exposure had no significant effect on CSR disclosure.
\end{abstract}

Keywords: CSR Disclosure, Media Exposure, Managerial Ownership, ISR Award.

\section{INTRODUCTION}

Corporate Social Responsibility (CSR) is a management concept whereby companies integrate social and environmental concerns in their business operations and interactions with their stakeholders. By acting responsibly to various social, environmental, and economic pressures, a company responds to various stakeholders' expectations, such as employees, shareholders, investors, consumers, public authorities, and non-governmental organizations [1]. Indonesia has provided several legal terms for the implementation of CSR, including Law Number 32/2009 on Protection and Management of Environment, Law Number 40/2007 on PT (Perseroan Terbatas) or Limited Corporation, Government Regulation Number 47/2012 on Environment and Social Responsibility of Perseroan Terbatas (Limited Corporation), and Law Number 25/2007 on Investments. All of these regulations require companies to be socially and environmentally responsible to the public. Amid the strong and clear legal basis for corporate social responsibility practices and disclosures, the implementation seems to lack good standards - some companies performed well, while others were not obedient to the disclosure practice [2].
The strong and clear legal basis for CSR disclosure has not been able to motivate companies to handle the matter well. In other words, shareholders and management teams must be better committed to prioritizing environmental and social issues and part of their company's business strategies. The unstandardized implementation of CSR in companies can be clearly seen from the varied ways companies disclose CSR. Studies suggest that CSR disclosure was low among public companies in Indonesia, which was less than $50 \%$, with mining companies rank first in practice [2]-[5]. The gap had been why we conducted the study since we wanted to reveal companies' motivation to disclose their CSR voluntarily.

Two theories exist related to CSR disclosure, namely the signaling theory and the legitimacy theory. Consistent with these two theories, the award received for CSR activities by the company is seen as a positive signal and is an acknowledgment of legitimacy from stakeholders. Boesso and Kumar showed the relationship between the level of voluntary disclosure practices and winning awards [6]. Besides, winning an award is considered a company's strategy to gain reputation and legitimacy. Based on the Public Listing Company Survey in 
Malaysia Haniffa and Cooke confirmed that one of the companies' motivations to disclose CSR is to get an award, [6]. Anas, Rashid, and Anuar revealed a similar result from the study on companies in Malaysia, showing differences in CSR disclosure level between companies who won awards and companies who did not [7]. In this regard, the Indonesia Sustainability Reporting Awards (ISRA) is awarded to public companies for CSR disclosure quality. This study included ISRA as a variable motivating company to disclose CSR better.

Another variable believed to influence varied CSR disclosure is managerial ownership; it was chosen for two views that relate managerial ownership with CSR disclosure. CSR requires commitment from management to allocate company resources without compromising the owners' welfare. Allocating company resources for CSR activities often creates conflicts of interest. On the one hand, managerial ownership is considered able to align the interests of management and owners-companies with large managerial ownership will have greater motivation to carry out CSR activities and disclose them to the public. On the other hand, when managerial ownership is becoming more prominent, companies are more reluctant to allocate resources for CSR activities [8]. Several studies have found inconsistent results regarding the effect of managerial ownership on CSR disclosure. Trisnawati discovered a positive effect of managerial ownership on CSR disclosure [9], while several studies confirmed no effect [10]-[12]. Some research conducted in Jordan and Malaysia resulted in negative effects of managerial ownership on CSR disclosure [13]-[15].

Moreover, the media plays an essential role in social mobilization [16]. The media can be used as a strategic instrument in terms of public scrutiny to provide psychological pressure to companies, so that awareness of social-environmental issues arises, and it is expected to encourage companies to disclose more social activities. Several studies have uncovered that media exposure positively affected CSR disclosure [16], [17], [18]. However, other studies have also confirmed that media exposure did not affect CSR disclosure [2], [3]. One reason for the difference in the results is the difference in measuring the media exposure variable. This present study defines media exposure as the extent to which media coverage reaches the company. Media reporting as a motivator for CSR disclosure can be explained by both signaling and legitimacy theory. Negative media reporting is seen as bad news that will pressure companies, and CSR disclosure is considered a response to eliminate the bad news and strategies to gain legitimacy. Positive media reporting about companies will be good news that encourages companies to increase disclosure, consistent with the signaling theory.

This study aimed to examine the effect of media exposure, managerial ownership, and ISRA on CSR disclosure. The research is expected to contribute to the development of studies on CSR disclosure in Indonesia in two ways. First, our study included the ISRA variable as a determinant of CSR disclosure - the award has not been studied much in Indonesia for its influence on the CSR disclosure level. During 2010-2020, ISRA was only tested for its effect on financial performance, abnormal returns, and stock trading volume; it was used merely as a sample criterion without being included as a research variable in the research model as in the study conducted by Adistie and Bandi [19]. Second, the present study classified media exposure into positive and negative media exposure to test whether the two theories (signaling and legitimacy theory) could explain the motivation of disclosure through media exposure.

\section{LITERARURE REVIEW}

\section{Legitimacy Theory}

Dowling and Pfeffer explained that legitimacy theory is drawn from the organizational legitimacy concept, which is defined as a condition or status that exists when an entity's value system is congruent with the larger social system's value system of which the entity is a part [20]. When a disparity, actual or potential, exists between the two value systems, there is a threat to the entity's legitimacy. Therefore, legitimacy theory can comprehensively explain social and environmental responsibility disclosure because it clearly recognizes that every business process must be bound by an environmental-social contract, where the organization agrees to carry out its socially desirable activities [21]. CSR disclosure is how companies can legitimize their existence and sustainability for the community to allow the company's activities to continue running [22]. Also, according to Patten, the legitimacy theory elucidates that the company also uses its efforts to disclose information on corporate responsibility activities to the social environment as a means to respond to and participate in public policy processes [23] .

\section{Signaling Theory}

The signaling theory explicates the existence of information asymmetry between the owner of the information (the company) and the user of the information (i.e., internal and/or external stakeholders). In this case, the company has the intention to signal its superiority compared to other companies by disclosing the quality of the company (good news) [24]. In this present study, the signaling theory explained the factor driving the company to communicate positive company information to convey company policies and activities that have added value to the company. Therefore, the signaling theory and this study's object, which was CSR disclosure, had such a close relationship in which the disclosure represented the company's effort in signaling its quality to minimize information asymmetry. 


\section{Agency Theory}

According to [25], agency theory details the relationship between a company's owner and manager . The company owner delegates the agent (manager) to exercise the authority to make decisions and manage the company. In this relationship, if the roles of the company's owner and manager are simultaneously carried out by the same party because the manager has a large proportion of the company's shares, the decision quality control function can be strengthened, and agency conflicts can be mitigated. In this study, we believe that managerial ownership harmed CSR disclosure because, in addition to being a managing agent, the manager also acted as the company's owner. Thus, decisions taken would prioritize managers' interests - with consideration of personal financial benefits.

\section{The Influence of Media Exposure on CSR Disclosure}

Media exposure is defined as reports by mass media that highlight companies [2]. With companies being highlighted by the media, companies will be more careful in making decisions. The more frequent companies are reported by the mass media, the public will grow more aware that it puts companies as an object of public attention-which finally leads to public supervision. News about a company can be a monitoring mechanism and can provide psychological pressure to the company to be more concerned and careful about its activities. Thus, the company will be encouraged to continue to maintain business activities, operational activities, social activities, and market appraisals to remain positive. Therefore, media coverage will become a social control for companies to continue to disclose CSR well.

The motivation of CSR disclosure by companies related to media exposure can be explained by two theories: signaling and legitimacy theory. The first theory is related to good reporting, while the latter explains the relationship between bad reporting and disclosure. If the mass media presents much bad news about a company, it will try to eliminate the negative media exposure by disclosing CSR. CSR disclosure is seen as a strategy to maintain the company's reputation and image to offset negative media exposure. Thus, the more negative exposure a company receives, the more it will disclose its CSR to obtain society's legitimacy. This explanation is consistent with the theory of legitimacy. On the other hand, upon receiving positive media exposure, a company will encourage its CSR disclosure to strengthen positive signals about its business - this is in line with the signaling theory, saying that the company will publish good news voluntarily. Based on the aforementioned explanations, the media's good and bad news will motivate companies to disclose CSR, consistent with the signaling and legitimacy theory. Therefore, we proposed the following hypotheses:
H1a: Positive media exposure has a positive effect on CSR disclosure.

H1b: Negative media exposure has a positive effect on CSR disclosure.

\section{The Influence of Managerial Ownership on CSR Disclosure}

Sari and Rani defined managerial ownership as the proportion of shares owned by managers over the company shares they manage [12]. Two opinions exist about the effect of stock ownership by managers on CSR disclosure. Based on the agency theory, when the managerial ownership becomes more prominent, the information asymmetry can no longer play a key role in controlling managers to prioritize the company's interests, enhancing the company's reputation by allocating resources for CSR activities. It is due to the decreasing possibility of agency conflict between shareholders and company managers, in this case, managers. Besides, according to Barnea and Rubin, directors or managers who own shares in the companies they manage will be reluctant to invest more in CSR activities because they will bear (some of) the costs since they also play a role as shareholders [8]. Thus, the bigger the managerial ownership, the lower the CSR disclosure level will be. Based on the explanation, we proposed the following hypothesis:

H2: Managerial ownership negatively influences CSR disclosure.

\section{The Influence of ISRA Award on CSR Disclosure}

According to Anas, Rashid, and Anuar, an award is a form of appreciation given by the authorities and nongovernmental organizations to public companies to contribute to social life, reflected through its activities promote community sustainability and social sustainability [7]. Following previous research, we defined ISRA as an award given to measure a company's interest in non-profit activities. In other words, it deals with the importance of sustainability in its activities, including in expressing CSR. An empirical study by Deegan and Carroll revealed that awards play a vital role in motivating social and environmental disclosure practices [26]. Haniffa and Cooke conducted a survey employing questionnaires that examined the attitude of the Malaysian Public Listing Companies towards CSR disclosure - the result confirmed that one of the motivations for companies to disclose CSR was the awards [27].

In another study, Boesso and Kumar showed the relationship between the level of voluntary disclosure practices and winning awards. For companies that have received awards for good CSR practices, the legitimate gap between the company and the community is smallsmaller compared to companies that have not received 
such awards [6]. Companies are motivated to carry out CSR activities to get awards because awards help companies gain a better image in the eye of the public, shareholders, and other external parties. It is also in line with the company's efforts to legitimize its existence to the community because it has carried out CSR activities well. Based on these explanations, companies that have received ISRA are believed to be more motivated to increase their CSR disclosure in the following year. Thus, we proposed the following hypothesis:

H3: ISRA has a positive effect on CSR disclosure.

\section{METHODOLOGY}

\section{Data \& Sample}

The research object was CSR disclosure in sustainability, and the research subjects were companies listed on the Indonesia Stock Exchange that published sustainability reports during the 2017-2018 period. Research data was in the form of secondary data obtained from sustainability and financial reports, media reports from the mass media, and ISRA from the National Center for Sustainability Reporting (NCSR) website. As many as 40 public companies published their sustainability reports in the 2017-2018 periods. The research samples were chosen based on a match proportionally - they were companies that won and did not win ISRA in the same industry category.

\section{Operational Variables}

\section{CSR Disclosure}

The dependent variable was CSR disclosure. According to Hackston and Milne, CSR disclosure is the information that a company shares about its environmental impact and its relationship with stakeholders using relevant communication to specific interest groups and society in general [28]. The measurement of CSR disclosure would refer to the fourth generation of GRI (GRI G4) disclosure indicators concerning the instruments used by Anggraeni and Djakman [29]. The G4 indicator was taken from www.globalreporting.org, with nine economic indicators, 48 social indicators, and 34 environmental indicators. Content analysis was employed to see CSR disclosure items in the sustainability report. A disclosed item would receive 1 point, and an undisclosed item would receive 0 . Then, the CSR disclosure index would be calculated using the following formula:

$$
\text { CSRDis }=\frac{\text { SCSR } \mathrm{i}}{\boldsymbol{S M C S R} \mathbf{i}} \times 100
$$

\section{Managerial Ownership}

Managerial ownership is the ratio of shares owned by all board members to total shares outstanding [30]. In this study, managerial ownership is defined as the proportion of shares owned by top-level managers, such as directors, commissioners, and the like. The managerial ownership variable was measured by the percentage of ownership of company shares, with the following formula:

$$
\mathrm{KM}=\frac{\text { TSM }}{\text { TSP }} \times 100
$$

\section{Media Exposure}

Media exposure in this study is defined as news in the mass media that highlight companies. In this case, media exposure represents public (community) oversight of company activities because the media plays an essential role in social mobilization [16]. Media exposure was assessed employing the number of news, classified between positive and negative news, that highlighted the sample companies, published by online newspapers, namely Detik newspapers, accessed through www.detik.com within one year (from January 1 to December 31) in each period. The searching was done by utilizing the Google search engine. The company name was used as a search keyword on the online media website. A calculation was made of all news in one year from the search results, and classification was made between positive and negative news. The total number of reports in the classification was employed to measure media exposure.

\section{ISRA (Indonesian Sustainability Reporting Award)}

The Indonesian Sustainability Reporting Award is a form of appreciation given by non-governmental organizations, the National Center for Sustainability Reporting (NCSR), in collaboration with the Institute of Certified Sustainability Practitioners (ICSP), to companies for their contribution in carrying out activities to promote sustainability. One of the evaluation criteria in this award is CSR disclosure for economic performance, environmental sustainability, and social life balance. The variable was determined on an ordinal scale by giving each winning category a rank - the higher the ISRA rank, the higher the score. ISRA variable used t-1 data (2016-2017). The scores referred to are as follows:

Table 1. The Score of ISRA

\begin{tabular}{|l|l|}
\hline Ranking Category & Score \\
\hline Best Overall & 4 \\
\hline Winner & 3 \\
\hline Runner Up 1 & 2 \\
\hline Runner Up 2 & 1 \\
\hline No award & 0 \\
\hline
\end{tabular}




\section{Company Size (control variable)}

Our study used the company size as a control variable. Company size represents the size of a company that can be assessed and measured by several proxies. As in this study, company size was calculated through a proxy for total company assets. The company size is defined as the natural logarithm of total assets at the end of the period (Ln.of Total Assets).

\section{Data Analysis Method}

The data were analyzed using descriptive statistics, classic assumption tests, and hypothesis testing. Multiple regression analysis was employed for hypothesis testing. Before conducting a regression analysis, classic assumption tests were carried out to ensure that normality, non-multicollinearity, homoscedasticity, and non-autocorrelation assumptions were met. The formulas used are as follows:

$$
\begin{aligned}
& \text { CSRDis }=\alpha+\beta 1 \mathrm{PMp}+\beta 2 \mathrm{PMn}-\beta 3 \mathrm{KM}+\beta 4 \mathrm{PISRA} \\
+ & \beta 5 \mathrm{UP}+\varepsilon
\end{aligned}
$$

Note: CSRDis = CSR disclosure; $\mathrm{PMp}=$ positive media exposure; $\mathrm{PMn}=$ negative media exposure; $\mathrm{KM}=$ managerial ownership; PISRA = ISRA; UP = company size.

\section{RESULTS}

\section{Descriptive Statistics}

We had 23 companies as samples in each period. Thus, the total samples were 46 companies from the property, finance, trade and investment, mining, agriculture, infrastructure, basic industry, and consumer goods industries. Table 2 presents the results of the descriptive statistics.

Table 2. Descriptive Statistics

\begin{tabular}{|c|l|l|l|l|r|}
\hline Variables & $\mathbf{N}$ & Min & Max & Average & $\begin{array}{l}\text { Std. } \\
\text { Deviation }\end{array}$ \\
\hline CSRDis & 46 & 16.48 & 73.63 & 45.4143 & 16.90366 \\
\hline PMp & 46 & 0.00 & 190.00 & 35.0435 & 58.75068 \\
\hline PMn & 46 & 0.00 & 46.00 & 9.3261 & 13.59421 \\
\hline KM & 46 & 0.00 & 9.95 & 0.6681 & 2.06874 \\
\hline PISRA & 46 & 0.00 & 4.00 & 0.6087 & 1.29062 \\
\hline UP & 46 & 28.55 & 34.75 & 31.1152 & 1.36355 \\
\hline
\end{tabular}

Table 2 depicts that CSR disclosure (CSRDis) had an average score of $45.41 \%$, with the lowest score of $16.48 \%$ and the highest score of $73.63 \%$. Both the highest and the lowest scores were for the finance industry. The media presented more good news (positive) with an average of 35 news than bad news (negative) with an average of nine news. Managerial ownership in the company was relatively small, with an average of $0.6681 \%$. More companies $(60.33 \%)$ received ISRA than the average of $45.4 \%$; it indicated a correlation between ISRA and CSR disclosure level.

\section{Hypothesis Testing Results}

Before testing the hypotheses, a classic assumption test was performed. The normality test results showed that the Kolmogorov-Smirnov value had an Asymp. Sig2 Tailed of 0.767 , so the normality assumptions were met. The multicollinearity test results revealed that all variables had a higher tolerance value than 0.10 and a VIF value of less than 10 , so the regression model was free of multicollinearity. Heteroscedasticity and autocorrelation test results showed that the regression model met the assumption of homoscedasticity and nonautocorrelation (the Durbin-Watson value was 2.216).

The correlation test results indicated that positive media exposure (PMp) and CSR disclosure, as well as ISRA (PISRA) and CSR disclosure, after being controlled by company size, had a weak correlation, while negative media exposure (PMn) and CSR disclosure became uncorrelated. These results signified that the effect of negative media exposure did not correlate with CSR disclosure in big companies.

The determination coefficient test results revealed an adjusted R2 value of 0.611 , meaning that the research model used could explain the dependent variable as much as $61.1 \%$. The F-test value was 15.127 with a p-value of 0.000 ; these results indicated that the research model was good enough.

\begin{tabular}{|c|c|c|c|c|c|}
\hline \multirow[t]{2}{*}{ Variables } & \multicolumn{2}{|c|}{$\begin{array}{l}\text { Unstandardized } \\
\text { Coefficients }\end{array}$} & \multirow{2}{*}{$\begin{array}{l}\text { Standard } \\
\text { ized } \\
\text { Coefficie } \\
\frac{\text { nts }}{\text { Beta }}\end{array}$} & \multirow[t]{2}{*}{$\mathrm{t}$} & \multirow[t]{2}{*}{ Sig. } \\
\hline & B & $\begin{array}{l}\text { Std. } \\
\text { Error }\end{array}$ & & & \\
\hline $\begin{array}{l}\text { (Cons } \\
\operatorname{tant})^{-}\end{array}$ & $\begin{array}{c}- \\
174.93 \\
\end{array}$ & $838^{45 .}$ & - & $\begin{array}{r}- \\
3.816 \\
\end{array}$ & $000^{0 .}$ \\
\hline PMp & $033^{.1}$ & $47^{0.0}$ & $\begin{array}{ll} & 0.35 \\
7 & \\
\end{array}$ & $208^{2 .}$ & $033^{0 .}$ \\
\hline PMn & $.267^{-}$ & $21^{0.2}$ & 0.215 & $\begin{array}{r}- \\
1.211 \\
\end{array}$ & $233^{0 .}$ \\
\hline $\mathrm{KM}$ & $.414^{-}$ & $95 \quad$ & $\begin{array}{r}- \\
0.051 \\
\end{array}$ & $\begin{array}{r}- \\
0.521\end{array}$ & $606^{0 .}$ \\
\hline $\begin{array}{rr} & \text { PISR } \\
\text { A } & \\
\end{array}$ & $638^{3 .}$ & $488^{1.3}$ & $\begin{array}{ll} & 0.27 \\
8 & \\
\end{array}$ & $698^{2 .}$ & $010^{0 .}$ \\
\hline UP & $984^{6 .}$ & 96 & $\begin{array}{ll} & 0.56 \\
3 & \end{array}$ & $668^{4 .}$ & $000^{0 .}$ \\
\hline
\end{tabular}

Table 3. Hypothesis Testing Result

Table 3 presents the following information:

Hypothesis 1 Testing: The Influence of Media Exposure on CSR Disclosure.

Hypothesis 1a (H1a) results showed that positive media exposure had a positive effect on CSR disclosure. The result supports previous research by Zhang and 
Chen; and Hasnia and Rofingatun that media exposure (media coverage) had a significant effect on CSR disclosure [17], [31]. It indicated that positive exposure by the media made managers of companies compelled to express CSR. Hypothesis 1a test results also confirmed the signaling theory. It could be said that with the increasing number of positive exposure by the media, managers were increasingly motivated to signify CSR activities and increase CSR disclosure. Besides, the results of testing Hypothesis $1 \mathrm{~b}(\mathrm{H} 1 \mathrm{~b})$ revealed that negative media exposure did not significantly influence CSR disclosure. The result not supports previous research by Bo that the negative exposure by the media had a positve effect on CSR disclosure [18]. It aligns with research by Widiastuti, Utami, and Handoko (2018) that the media exposure variable did not affect CSR disclosure. Our study failed to confirm the legitimacy theory as a motivation for CSR disclosure. Negative media exposure did not encourage managers to increase CSR disclosure as an effort to eliminate negative coverage and maintain their legitimacy. The two hypotheses' test results above indicated that CSR disclosure was more motivated by giving signals rather than gaining legitimacy when it came to media exposure.

Hypothesis 2 Testing: The Influence of Managerial Ownership on CSR Disclosure

Table 3 illustrates that managerial ownership had a probability value of 0.606 with a regression coefficient of -0.414. It indicated that managerial ownership did not significantly influence the CSR disclosure level. This result corroborates the research by Sari and Rani, Nasir et al., and Nurrahman and Sudarno that managerial ownership did not have a significant impact on CSR disclosure in Indonesia [10]-[12]. The average managerial ownership in this study was relatively small $(0.6681 \%)$ that it was considered insufficient to provide a significant boost to managers' decisions in determining CSR disclosure policies of the company. Low managerial ownership played no role in aligning the interests of management and owners.

Hypothesis 3 Testing: The Influence of ISRA on CSR Disclosure.

The results of testing hypothesis 3 (H3) uncovered that ISRA had a significant positive effect on CSR disclosure. These results are in line with previous research by Anas, Rashid, and Annuar; Boesso and Kumar; and Haniffa and Cooke that the award variable had a significant positive effect on the disclosure level [6], [7], [27]. Besides, the results of testing hypothesis 3 (H3) successfully confirmed the legitimacy theory, which explains that an entity needs recognition from the environment in which it is located. As a public company, an entity in the community, the need to get recognition from legal entities is indispensable because it can help improve the company's value and image in public. This finding also confirmed the signaling theory. Winning
ISRA then became a positive signal for companies since it would motivate them to increase CSR disclosure in the following year.

\section{CONCLUSIONS}

This study aimed to obtain empirical evidence about the effect of media exposure, managerial ownership, and ISRA on CSR disclosure by including company size as a controlling variable. The samples were companies listed on the Indonesian Stock Exchange as a public company that published sustainability reports. There were 46 samples, 23 companies per year during the two-year study from 2017 to 2018 , from various industrial sectors. Our findings confirmed that positive media exposure and ISRA had a significant positive effect on CSR disclosure, while negative media exposure and managerial ownership did not affect CSR disclosure. Our study had successfully confirmed the role of the signaling theory and legitimacy theory through positive media exposure and ISRA.

This study will bring implications for policies related to CSR disclosure. Policymakers need to design a policy framework that encourages public companies to participate in annual sustainability award events. The award is expected to motivate many public companies to issue sustainability reports. The media also has an essential role as social control and motivator for companies to prioritize sustainable development activities and present the implementation reports.

The small number of research samples and the use of online media (Detik) have become the limitations of the present study since it may not yet describe the overall media coverage. Besides, CSR disclosure was measured in terms of quantity, so it did not reflect the disclosure quality. Future studies can increase the number of samples and improve the measurement of CSR disclosure by providing weighting.

\section{REFERENCES}

[1] I. M. Garcia-Sanchez, B. Cuadrado-Ballesteros, and C. Sepulveda, "Does media pressure moderate CSR disclosures by external directors?," Manag. Decis., vol. 52, no. 6, pp. 1014-1045, 2014.

[2] H. Widiastuti, E. R. Utami, and R. Handoko, "Pengaruh Ukuran Perusahaan, Tipe Industri, Growth, dan Media Exposure terhadap Pengungkapan Tanggung Jawab Perusahaan (Studi Empiris pada Perusahaan yang Terdaftar di Bursa Efek Indonesia Tahun 2014-2015)," Ris. Akunt. dan Keuang. Indones., vol. 3, no. 2, pp. 107-117, 2018.

[3] B. Solikhah and A. M. Winarsih, "Pengaruh Liputan Media, Kepekaan Industri, Dan Struktur Tata Kelola Perusahaan Terhadap Kualitas Pengungkapan Lingkungan (The Effect Of Media Coverage, 
Industry Sensitivity And Corporate Governance Structure On Environmental Disclosure Quality)," J. Akunt. dan Keuang. Indones., vol. 13, no. 1, pp. 1-22, 2016.

[4] S. Munsaidah, R. Andini, and A. Supriyanto, "Analisis Pengaruh Firm Size, Age, Profitabilitas, Leverage, dan Growth Perusahaan terhadap Corporate Social Rerponsibility (CSR) pada Perusahaan Property dan Real Estate yang Terdaftar di Bursa Efek Indonesia Pada Tahun 2010-2014," J. Account., vol. 2, no. 2, pp. 1-11, 2016.

[5] I. G. A. L. Indraswari and N. P. S. H. Mimba, "Pengaruh Profitabilitas, Pertumbuhan Perusahaan, Kapitalisasi Pasar, dan Kepemilikan Saham Publik pada Tingkat Pengungkapan CSR," E-Jurnal Akunt. Univ. Udayana, vol. 20, no. 2, pp. 1219-1248, 2017.

[6] G. Boesso and K. Kumar, Drivers of corporate voluntary disclosure: A framework and empirical evidence from Italy and the United States, vol. 20, no. 2. 2007.

[7] A. Anas, H. M. A. Rashid, and H. A. Annuar, "The Effect of Award on CSR Disclosures in Annual Reports of Malaysian PLCs," Soc. Responsib. J., vol. 11, no. 4, pp. 831-852, 2015.

[8] A. Barnea and A. Rubin, "Corporate Social Responsibility as a Conflict Between Shareholders," J. Bus. Ethics, vol. 97, no. 1, pp. 71-86, 2010.

[9] R. Trisnawati, "Pengaruh Ukuran Perusahaan, Profitabilitas, Leverage, Ukuran Dewan Komisaris dan Kepemilikan Manajerial Terhadap Pengungkapan Corporate Social Responsibility (CSR) Industri Perbankan di Indonesia," Semin. Nas. dan Call Pap., no. October, pp. 27-32, 2014.

[10] A. Nurrahman and S. Sudarno, "Pengaruh Kepemilikan Manajerial, Kepemilikan Institusional, Dan Kepemilikan Asing Terhadap Praktik Pengungkapan Sustainability Report," Diponegoro J. Account., vol. 0, no. 0, pp. 273-285, 2013.

[11] A. Nasir, P. Kurnia, and T. Hakri, "Pengaruh Kepemilikan Manajerial, Leverage, Profitabilitas, Ukuran, dan Umur Perusahaan terhadap Pengungkapan Informasi Pertanggungjawaban Sosial Perusahaan pada Perusahaan Food and Beverage yang Terdaftar di BEI," J. Ekon., vol. 21, pp. 1-14, 2013.

[12] W. N. Sari and P. Rani, "Pengaruh Kepemilikan Institusional, Kepemilikan Manajerial, Return on Assets (ROA) dan Ukuran Perusahaan terhadap Pengungkapan Corporate Social Responsibility (CSR) pada Perusahaan Manufaktur yang Terdaftar di Bursa Efek Indonesia Periode 2011-2013," J. Akunt. dan Keuang., vol. 4, 2015.

[13] N. A. M. Ghazali, "Ownership structure and corporate social responsibility disclosure: Some Malaysian evidence," Corp. Gov., vol. 7, no. 3, pp. 251-266, 2007.

[14] Nurleni, A. Bandang, and A. Amiruddin, "The Effect of Managerial and Institutional Ownership on Corporate Social Responsibility Disclosure," Int. J. Law Manag., vol. 60, no. 4, pp. 979-987, 2017.

[15] M. B. Abu Qaa'dan and M. S. Suwaidan, "Board composition, ownership structure and corporate social responsibility disclosure: the case of Jordan," Soc. Responsib. J., vol. 15, no. 1, pp. 28-46, 2019.

[16] C. Reverte, "Determinants of corporate social responsibility disclosure ratings by Spanish listed firms," J. Bus. Ethics, vol. 88, no. 2, pp. 351-366, 2009.

[17] Z. Zhang and H. Chen, "Media coverage and impression management in corporate social responsibility reports: Evidence from China," Sustain. Accounting, Manag. Policy J., vol. 11, no. 5, pp. 863-886, 2019.

[18] W. Bo, "Negative Media Coverage and Corporate Social Responsibility — Empirical Evidence from Chinese A - Share Listed Companies," Int. J. Bus. Econ. Res., vol. 6, no. 4, p. 61, 2017.

[19] G. R. Adistie and M. H. Bandi, “Analisis Faktor Penghargaan Indonesia Sustainability Reporting Awards terhadap Pengungkapan Sosial," J. Anlisa Akunt. dan Perpajak., vol. 3, no. 1, pp. 29-39, 2019.

[20] J. Dowling and J. Pfeffer, "ORGANIZATIONAL LEGITIMACY: Social Values and Organizational Behavior between the Organizations seek to establish congruence," Pac. Sociol. Rev., vol. 18, no. 1, pp. 122-136, 1975.

[21] N. Brown and C. Deegan, "The Public Disclosure of Environmental Performance Information - A Dual Test of Media Agenda Setting Theory and Legitimacy Theory," Account. Bus. Res., vol. 29, no. 1, pp. 21-41, 1998.

[22] R. Gray, R. Kouhy, and S. Lavers, "Corporate Social and Longitudinal Study Of UK Disclosure," Accounting, Audit. Account. J., vol. 8, no. 2, pp. 4777, 1995.

[23] D. M. Patten, "The Relation between Environmental Performance and Environmental Disclosure: A Research Note," Accounting, Organ. Soc., vol. 27, no. 8, pp. 763-773, 2002. 
[24] B. L. Connelly, S. T. Certo, R. D. Ireland, and C. R. Reutzel, "Signaling Theory: A Review and Assessment," J. Manage., vol. 37, no. 1, pp. 39-67, 2011.

[25] M. Jensen and W. Meckling, "Theory of the firm: Managerial behavior, agency costs, and ownership structure," Econ. Nat. Firm A Reader, Third Ed., vol. 3, no. 4, pp. 305-360, 1976.

[26] C. Deegan and G. Carroll, "An Analysis of Incentives for Australian Firms to Apply for Reporting Excellence Awards," Account. Bus. Res., vol. 23, no. 91, pp. 219-227, 1993.

[27] R. M. Haniffa and T. E. Cooke, "The Impact of Culture and Governance on Corporate Social Reporting," J. Account. Public Policy, vol. 24, no. 5, pp. 391-430, 2005.

[28] H. David and J. Milne, Markus, "Some Determinants of Social and Environmental Disclosuresin New Zealand Companies," Accounting, Audit. Account. J., vol. 9, no. 1, pp. 77108, 1996.

[29] D. Y. Anggraeni and C. D. Djakman, "Pengujian terhadap Kualitas Pengungkapan CSR di Indonesia," Ekuitas J. Ekon. dan Keuang., vol. 2, no. 1, pp. 22-41, 2018.

[30] M. Namazi and E. Kermani, “An Empirical Investigation of the Relationship between Corporate Ownership Structures and their Performances (Evidence from Tehran Stock Exchange)," $J$. Financ. Account., vol. 1, no. 1, pp. 13-26, 2013.

[31] Hasnia and S. Rofingatun, "Pengaruh Profitabilitas, Likuiditas, Growth dan Media Exposure terhadap Pengungkapan Tanggung Jawab Sosial Perusahaan (Studi Empiris pada Perusahaan Manufaktur dan Perusahaan Jasa yang Terdaftar di Bursa Efek Indonesia Tahun 2013-2015)," J. Akunt. Keuang. Drh., vol. 12, no. 2014, pp. 56-71, 2017. 